\title{
What Has Gone Wrong With Japan's Stock Performance Over the Last Three Decades?
}

\author{
Yan He \\ Indiana University Southeast \\ Frank Long \\ (Corresponding Author) \\ Wuhan University \\ Duke Kunshan University \\ Strategic Decision Research Center
}

\begin{abstract}
Japan has a poor stock performance compared with the US in three decades (1989-2019). At the end of 1989, the Nikkei 225 Index reached its all-time high (38,916); by the end of 2019, the index was 23,657, a change of $-39 \%$ over the entire period. Meanwhile, the $S \& P 500$ Index increased from 353 to 3,231, a change of $815 \%$. To comprehend this matter, we investigate the areas of economic conditions, corporate governance, corporate financial policies, corporate financial performance, and relative valuation. Our research method is a combination of qualitative and quantitative approaches. Our analyses reveal a variety of problems: slow GDP growth, weak legal protections and low governance ratings, insiders-dominated and cross-holding ownership structure, excess financial assets, low profitability, slow growth of earnings and revenues, and contraction of relative valuation. In the most recent decade (2009-2019), we note some improvements: expansionary monetary policy, productivity growth, better corporate governance, increased dividend payments and stock repurchases, earnings growth, and enhanced profitability. Therefore, Japan's transformation is substantial, though it is gradual and incomplete.
\end{abstract}

Keywords: Japanese stock performance, Japanese economy, Japanese financial management

\section{INTRODUCTION}

The Japanese stock market has a poor performance in the last three decades as a whole (1989-2019). In 1989, the Nikkei 225 Index reached its all-time high (nearly 39,000); in 2018, the index was still 40\% below its all-time high, even though the Japanese economy was about $60 \%$ larger than that of 1989 (Glassman, 2018). Moreover, Japan's market capitalization was $45 \%$ of the global stock market in 1989; in 2017, it was only $8.4 \%$ (Richards, 2017). Therefore, equity investors in the world cannot help wondering what has gone wrong with Japan's long-term stock performance.

In the most recent decade (2009-2019), however, the Japanese stock market has achieved decent returns. As Bird (2019b) points out, the performance of Japanese stocks is ranked second globally during 
this period and their earnings growth matches that of US stocks. Is such a trend sustainable? Is it a turning point or merely another false start?

The long-term economic goal of a business is to maximize the average annual rate of gain in intrinsic business value on a per-share basis. Although intrinsic value and market price may diverge in the shortterm, they do converge in the long-term. Japan's dreadful stock performance in the last three decades certainly suggests its sluggish value enhancement (or even value reduction), which goes against the objective of business practices and indicates the inefficiency in utilizing capital. It is not only a challenge to Japan but also to Europe and many other economies.

In this paper, we attempt to explore the economic and financial issues that illuminate the challenge to Japan's business value enhancement. In our analyses, these issues are categorized into five areas: economic conditions, corporate governance, corporate financial policies, corporate financial performance, and relative valuation. As for the methodology, we collect, sort, and examine academic studies, newspaper articles, reports, and other forms of data. In the process, various theories in economic, legal, corporate, investment, and market systems are involved and integrated. Such a qualitative research approach is based on both grounded theory and systems theory, which allows us to achieve logical and cohesive understandings of the subject matter. Additionally, we also conduct some quantitative tests and computations in order to complement the evidence presented by the existing literature.

Across the five areas of our analyses, we examine a variety of serious and/or persistent problems that shed light on the poor stock performance of Japan. They include slow GDP growth, weak legal protections and low governance ratings, insiders-dominated and cross-holding ownership structure, excess financial assets, low profitability, slow growth of earnings per share (EPS) and revenues, and contraction of relative valuation.

\section{An Overview of Stock Performance for Three Decades}

Figure 1 displays the daily Nikkei 225 Index levels in the period 1989-2019 and its overall downward trend. The index is calculated based on 225 Japanese stocks in the currency of Japanese Yen (JPY), displaying an all-time high of 38,915.87 on December 29, 1989 and a 30-year low of 7,054.98 on March 10, 2009. In contrast, Figure 2 displays daily S\&P 500 Index levels in the period 1989-2019 and its overall trend is upward. The index is calculated based on 500 US stocks in the currency of US Dollar (USD), showing a 30-year high of 3,240.02 on December 27, 2019 and a 30-year low of 295.46 on October 11, 1990 .

\section{FIGURE 1 \\ JAPAN: DAILY NIKKEI 225 INDEX LEVELS IN 1989-2019 (JPY)}

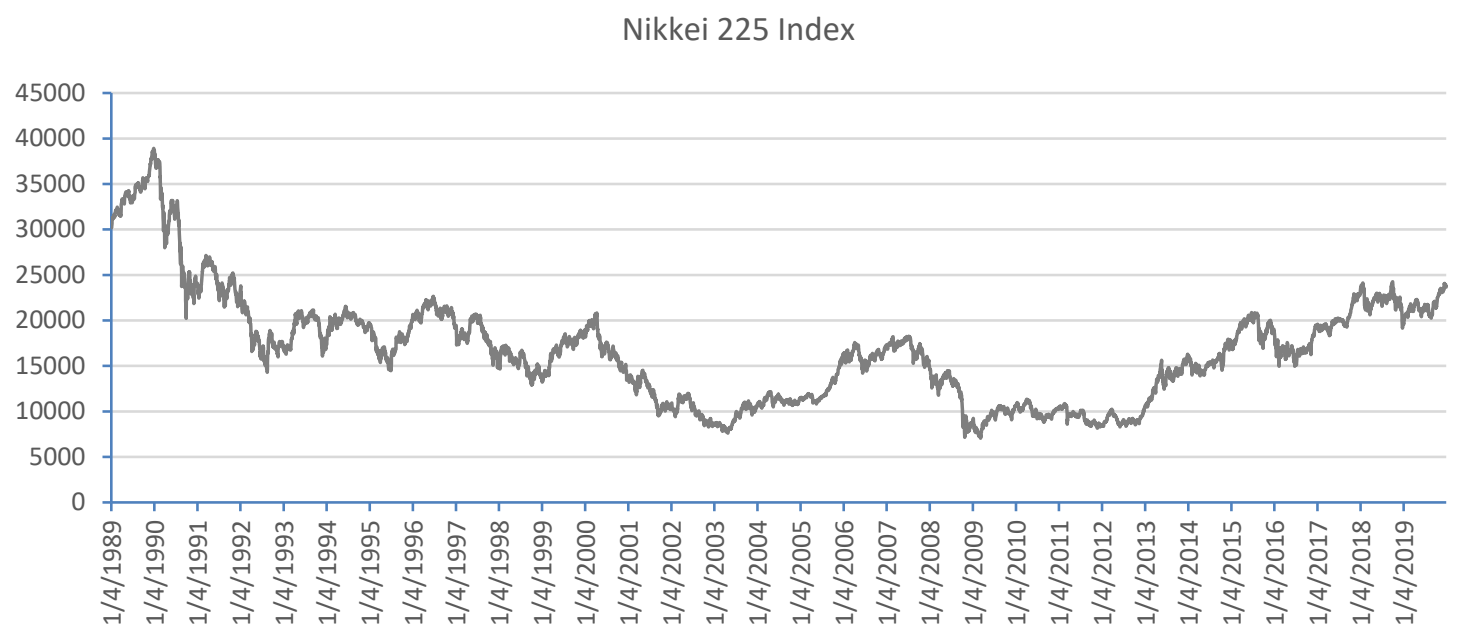

Source: Factset 
FIGURE 2

US: DAILY S\&P 500 INDEX LEVELS IN 1989-2019 (USD)

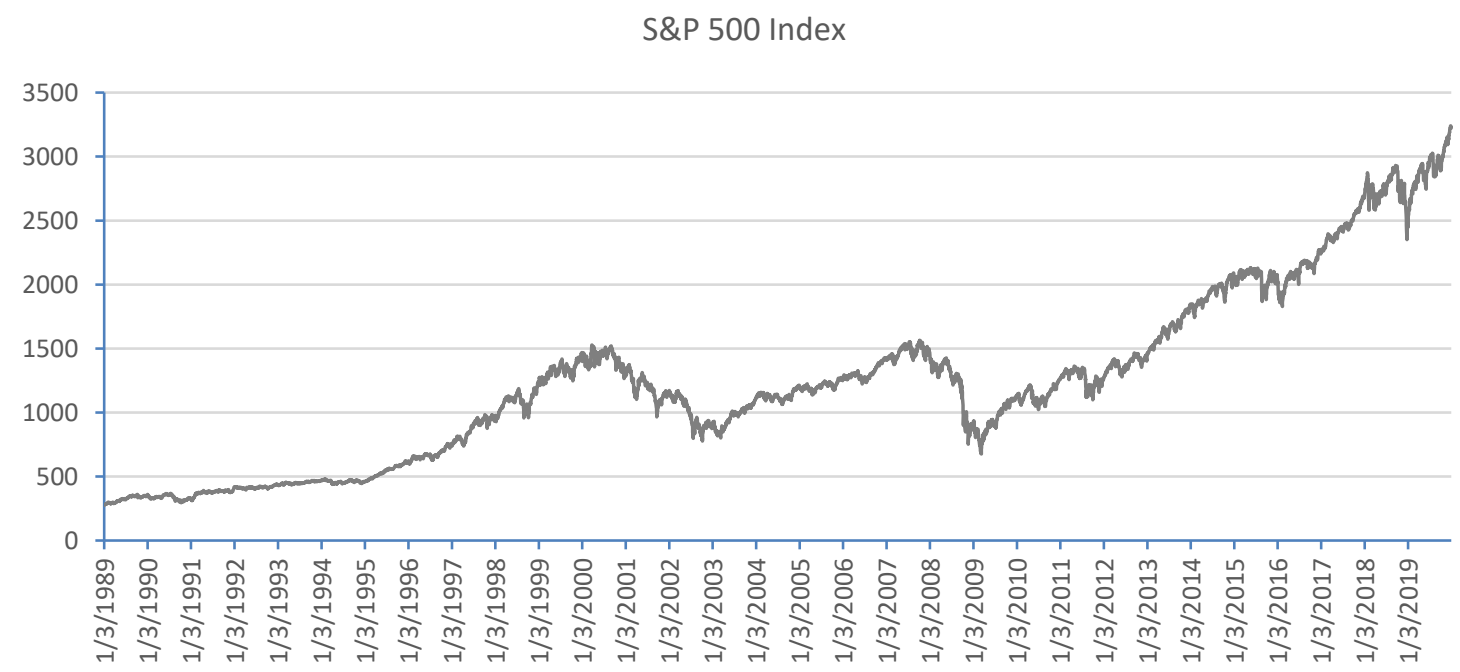

Source: Factset

Table 1 reports the annual returns of stock indexes for Japan and the US from the end of 1989 to the end of 2019. The annual return is calculated as the geometric mean of the percentage change in index levels. The Nikkei 225 Index in USD is calculated as the Nikkei 225 Index in JPY divided by the concurrent official exchange rate of JPY/USD. First, as Table 1 shows, during the entire three decades, the annual return of the Nikkei 225 Index is $-1.65 \%$ in JPY and $-0.91 \%$ in USD, much lower than $7.66 \%$ of the S\&P 500 Index in USD. Second, in each of the three decades, the annual returns of the Nikkei 225 Index in JPY and USD are lower than that of the S\&P 500 Index in USD.

TABLE 1

ANNUAL RETURNS OF STOCK INDEXES IN 1989-2019

\begin{tabular}{|l|c|c|c|}
\hline & $\begin{array}{c}\text { Japan: } \\
\text { Nikkei 225 Index } \\
\text { (JPY) }\end{array}$ & $\begin{array}{c}\text { Japan: } \\
\text { Nikkei 225 Index } \\
\text { (USD) }\end{array}$ & $\begin{array}{c}\text { S\&: } \\
\text { S\&P 500 } \\
\text { Index } \\
\text { (USD) }\end{array}$ \\
\hline Entire period: 1989-2019 & $-1.65 \%$ & $-0.91 \%$ & $7.66 \%$ \\
Annual return (geometric mean) & & & \\
\hline Sub periods: & $-6.95 \%$ & $-5.15 \%$ & $15.31 \%$ \\
Annual return (geometric mean), 1989-1999 & $-5.68 \%$ & $-3.81 \%$ & $-2.72 \%$ \\
Annual return (geometric mean), 1999-2009 & $8.41 \%$ & $6.63 \%$ & $11.22 \%$ \\
\hline Annual return (geometric mean), 2009-2019 & & & \\
\hline
\end{tabular}

Sources: Factset and World Bank (data.worldbank.org)

${ }^{1}$ The Nikkei 225 Index in USD is calculated as the Nikkei 225 Index in JPY divided by the concurrent official exchange rate of JPY/USD.

To explain the long-term downward and stagnant trend of the Japanese stock market, we investigate relevant issues across five areas in Section 3. A summary of the sources used in our analysis is provided in Table 2. Among all the subsections listed, the ones marked with a star sign are the serious and/or persistent problems contributing to the poor stock performance of Japan. 
TABLE 2

SUMMARY OF THE SOURCES USED IN THIS STUDY

\begin{tabular}{|c|c|}
\hline Section & Sources \\
\hline 1. Introduction & $\begin{array}{l}\text { - Glassman (2018) } \\
\text { - Bird (2019b) }\end{array}$ \\
\hline $\begin{array}{l}\text { 2. Stock Performance } \\
\text { in Three Decades }\end{array}$ & $\begin{array}{l}\text { - Figure 1. Japan: Daily Nikkei } 225 \text { Index levels in 1989-2019 } \\
\text { - Figure 2. US: Daily S\&P } 500 \text { Index levels in 1989-2019 } \\
\text { - Table 1. Annual returns of stock indexes in 1989-2019 }\end{array}$ \\
\hline $\begin{array}{l}\text { 3.1. Economic } \\
\text { conditions }\end{array}$ & $\begin{array}{l}\text { 3.1.1. Summary of economic conditions } \\
\text { - Hirakata, Sudo, Takei, and Ueda (2016) } \\
\text { - Table 3. Economic conditions in 1989-2019 } \\
\text { - Mackintosh (2019) } \\
\text { - Mun (2012) } \\
\text { - Aono and Iwaisako (2013) } \\
\text { - Ramdhan, Yousop, Ahmad, and Abdullah (2018) } \\
\text { 3.1.2. Negative economic aspects } \\
\text { - Table 3. Economic conditions in 1989-2019 } \\
\text { - Fujikawa and Narioka (2019) } \\
\text { - Fukuda and Yamada (2011) } \\
\text { - Glassman (2018) } \\
\text { - Rattner (2013) } \\
\text { - Miyazawa (2012) } \\
\text { - Cowling and Tomlinson (2000) } \\
\text { 3.1.3. Positive economic aspect } \\
\text { - Table 3. Economic conditions in 1989-2019 } \\
\text { - Allen, Carletti, and Grinstein (2018) } \\
\text { 3.1.4. Recent economic conditions } \\
\text { - Hausman and Wieland (2015) } \\
\text { - Fukuda (2018) } \\
\text { - Curran (2018) } \\
\text { - Bird (2019b) } \\
\text { - Bird (2019c and 2020) }\end{array}$ \\
\hline $\begin{array}{l}\text { 3.2. Corporate } \\
\text { governance }\end{array}$ & $\begin{array}{l}\text { 3.2.1. Summary of corporate governance } \\
\text { - Damodaran (2014) } \\
\text { 3.2.2. Weak legal protections and low governance ratings }{ }^{*} \\
\text { - La Porta, Lopez-de-Silanes, Shleifer, and Vishny (1998 and 2000a) } \\
\text { - Doidge, Karolyi, and Stultz (2007) } \\
\text { - Footnote 1. GMI Ratings }\end{array}$ \\
\hline
\end{tabular}




\begin{tabular}{|c|c|}
\hline Section & Sources \\
\hline $\begin{array}{l}\text { 3.2. Corporate } \\
\text { governance }\end{array}$ & $\begin{array}{l}\text { 3.2.3. All-stakeholders-centered objective } \\
\text { - Allen, Carletti, and Grinstein (2018) } \\
\text { - Diamond (2011) } \\
\text { - Yoshimori (1995) } \\
\text { 3.2.4. Insiders-dominated and cross-holding ownership structure* } \\
\text { - Franks, Mayer, and Miyajima (2014) } \\
\text { - La Porta, Lopez-de-Silanes, Shleifer, and Vishny (2000a) } \\
\text { - Prowse (1992) } \\
\text { - Kang, Shivdasani, and Yamada (2000) } \\
\text { - Morck, Nakamura, and Shivdasani (2000) } \\
\text { - Ikeda, Inoue, and Watanabe (2018) } \\
\text { - Chernenko, Foley, and Greenwood (2012) } \\
\text { - Hamao and Matos (2018) } \\
\text { - Mehrotra, Schaik, Spronk, and Steenbeek (2011) } \\
\text { 3.2.5. Recent changes in corporate governance } \\
\text { - Kato, Li, and Skinner (2017) } \\
\text { - Franks, Mayer, and Miyajima (2014) } \\
\text { - Hoshi, Koibuchi, and Schaede (2018) } \\
\text { - Miyajima, Ogawa, and Saito (2018) } \\
\text { - Bird (2019a) } \\
\text { - Warnock (2016) }\end{array}$ \\
\hline $\begin{array}{l}\text { 3.3. Corporate } \\
\text { financial policies }\end{array}$ & $\begin{array}{l}\text { 3.3.1. Summary of corporate financial policies } \\
\text { - Table 4. Corporate financial policies: Financial assets in 2011-2017 } \\
\text { - Table 5. Corporate financial policies: Debt and dividend in 1999-2019 } \\
\text { 3.3.2. Excess financial assets }{ }^{*} \\
\text { - Pinkowitz and Williamson (2001) } \\
\text { - Dittmar, Mahrt-Smith, and Servaes (2003) } \\
\text { - Khurana, Martin, and Pereira (2006) } \\
\text { - Riddick and Whited (2009) } \\
\text { - Azar, Kagy, and Schmalz (2016) } \\
\text { - Kato, Li, and Skinner (2017) } \\
\text { - Aoyagi and Ganelli (2017) } \\
\text { - Table 4. Corporate financial policies: Financial assets in 2011-2017 } \\
\text { - Luo and Hachiya (2005) } \\
\text { 3.3.3. High debt } \\
\text { - Dittmar, Mahrt-Smith, and Servaes (2003) } \\
\text { - Antoniou, Guney, and Paudyal (2008) } \\
\text { - Table 5. Corporate financial policies: Debt and dividend in 1999-2019 } \\
\text { - Khoo and Durand (2017) }\end{array}$ \\
\hline
\end{tabular}




\begin{tabular}{|c|c|}
\hline Section & Sources \\
\hline $\begin{array}{l}\text { 3.3. Corporate } \\
\text { financial policies }\end{array}$ & $\begin{array}{l}\text { 3.3.4. Low dividend \& share repurchase } \\
\text { - Chen (2012) } \\
\text { - L'Her, Masmoudi, and Krishnamoorthy (2018) } \\
\text { - Ide (1996) } \\
\text { - Dewenter and Warther (1998) } \\
\text { - La Porta, Lopez-de-Silanes, Shleifer, and Vishny (2000b) } \\
\text { - Pinkowitz, Williamson, and Stulz (2007) } \\
\text { - Kato, Li, and Skinner (2017) } \\
\text { - Table 5. Corporate financial policies: Debt and dividend in 1999-2019 } \\
\text { - Tong and Bremer (2016) }\end{array}$ \\
\hline $\begin{array}{l}\text { 3.4. Corporate } \\
\text { financial performance }\end{array}$ & $\begin{array}{l}\text { 3.4.1. Summary of corporate financial performance } \\
\text { - Koller, Goedhart, and Wessels (2015) } \\
\text { - Table 6. Corporate financial performance: Profitability in 1999-2019 } \\
\text { - Table 7. Corporate financial performance: Growth in 1989-2019 } \\
\text { 3.4.2. Low profitability }{ }^{*} \\
\text { - Ide (1996) } \\
\text { - Yanagi (2018) } \\
\text { - Table 6. Corporate financial performance: Profitability in 1999-2019 } \\
\text { - Schaede (2012) } \\
\text { - Curran (2018) } \\
\text { 3.4.3. Slow growth of EPS and revenues } \\
\text { - Table 7. Corporate financial performance: Growth in 1989-2019 } \\
\text { - Ide (1996) } \\
\text { - Kato, Li, and Skinner (2017) } \\
\text { - L'Her, Masmoudi, and Krishnamoorthy (2018) }\end{array}$ \\
\hline $\begin{array}{l}\text { 3.5. Relative } \\
\text { valuation }\end{array}$ & $\begin{array}{l}\text { 3.5.1. Summary of relative valuation } \\
\text { - Chan, Hamao, and Lakonishok (1991) } \\
\text { - Chan, Hamao, and Lakonishok (1993) } \\
\text { - } \quad \text { Fama and French (2012) } \\
\text { - Fukuta and Yamane (2015) } \\
\text { - Kubota and Takehara (2018) } \\
\text { 3.5.2. Contraction of relative valuation } \\
\text { - La Porta, Lopez-de-Silanes, Shleifer, and Vishny (2002) } \\
\text { - Table 8. Relative valuation in } 1989 \& 2019\end{array}$ \\
\hline
\end{tabular}

${ }^{*}$ Serious and/or persistent problems related to the poor stock performance of Japan.

\section{ANALYSES ACROSS THE FIVE AREAS}

\section{Economic Conditions}

Summary of Economic Conditions

Over the past three decades, the Japanese economy has experienced three large financial crises (Hirakata, Sudo, Takei, and Ueda, 2016). The first is the burst of the stock and land price bubbles during the early 1990s. The second is the collapse of some large financial institutions during the late 1990s. The 
third is the economic contraction aggravated by the global recession in the US and Europe during the late 2000s. In the entire period of three decades, the Japanese economy is characterized by slow growth and low inflation, with several mini recoveries that occurred for a while but all fizzled later. Table 3 presents the economic conditions of Japan and the US in 1989-2019. Panel A reports GDP growth rates based on geometric means and Panel B reports other economic data based on annual observations.

TABLE 3

ECONOMIC CONDITIONS IN 1989-2019

Panel A. GDP growth rates in 1989-2019

\begin{tabular}{|c|c|c|c|}
\hline & Japan (JPY) & Japan (USD) & US (USD) \\
\hline Entire period: $1989-2019$ & & & \\
\hline Annual nominal GDP growth rate (geometric mean) & $0.92 \%^{1}$ & $1.71 \%^{3}$ & $4.55 \%$ \\
\hline Annual real GDP growth rate (geometric mean) & $1.09 \%^{2}$ & $1.09 \%{ }^{4}$ & $2.46 \%$ \\
\hline Sub-period: $1989-1999$ & & & \\
\hline Annual nominal GDP growth rate (geometric mean) & $2.12 \%$ & $4.09 \%$ & $5.49 \%$ \\
\hline Annual real GDP growth rate (geometric mean) & $1.50 \%$ & $1.50 \%$ & $3.21 \%$ \\
\hline Sub period: $1999-2009$ & & & \\
\hline Annual nominal GDP growth rate (geometric mean) & $-0.60 \%$ & $1.38 \%$ & $4.14 \%$ \\
\hline Annual real GDP growth rate (geometric mean) & $0.50 \%$ & $0.50 \%$ & $1.89 \%$ \\
\hline Sub period: $2009-2019$ & & & \\
\hline Annual nominal GDP growth rate (geometric mean) & $1.24 \%$ & $-0.29 \%$ & $4.02 \%$ \\
\hline Annual real GDP growth rate (geometric mean) & $1.28 \%$ & $1.28 \%$ & $2.28 \%$ \\
\hline
\end{tabular}

Panel B. Other economic data in $1989-2019^{5}$

\begin{tabular}{|l|c|c|}
\hline & Japan & US \\
\hline Annual inflation rate, GDP deflator: mean & $-0.17 \%$ & $2.04 \%$ \\
Annual inflation rate, GDP deflator: median & $-0.51 \%$ & $2.02 \%$ \\
Annual inflation rate, GDP deflator: max & $2.93 \%$ & $3.74 \%$ \\
Annual inflation rate, GDP deflator: min & $-1.90 \%$ & $0.76 \%$ \\
\hline Annual inflation rate, consumer prices: mean & $0.47 \%$ & $2.45 \%$ \\
Annual inflation rate, consumer prices: median & $0.19 \%$ & $2.53 \%$ \\
Annual inflation rate, consumer prices: max & $3.25 \%$ & $5.40 \%$ \\
Annual inflation rate, consumer prices: min & $-1.35 \%$ & $-0.36 \%$ \\
\hline Annual yield of 10-year government bond: mean & $1.16 \%$ & $4.32 \%$ \\
Annual yield of 10-year government bond: median & $1.09 \%$ & $4.26 \%$ \\
Annual yield of 10-year government bond: max & $4.56 \%$ & $8.08 \%$ \\
Annual yield of 10-year government bond: min & $-0.02 \%$ & $1.76 \%$ \\
\hline Government debt as \% of GDP: mean & $134 \%$ & $77 \%$ \\
Government debt as \% of GDP: median & $150 \%$ & $66 \%$ \\
Government debt as \% of GDP: max & $202 \%$ & $113 \%$ \\
Government debt as \% of GDP: min & $48 \%$ & $55 \%$ \\
\hline
\end{tabular}




\begin{tabular}{|l|c|c|}
\hline & Japan & US \\
\hline Annual population growth rate: mean & $0.08 \%$ & $0.99 \%$ \\
Annual population growth rate: median & $0.09 \%$ & $0.95 \%$ \\
Annual population growth rate: max & $0.43 \%$ & $1.40 \%$ \\
Annual population growth rate: min & $-0.22 \%$ & $0.71 \%$ \\
\hline Unemployment rate: mean & $3.75 \%$ & $5.84 \%$ \\
Unemployment rate: median & $3.91 \%$ & $5.56 \%$ \\
Unemployment rate: max & $5.36 \%$ & $9.63 \%$ \\
Unemployment rate: $\min$ & $2.09 \%$ & $3.65 \%$ \\
\hline
\end{tabular}

Sources: Factset and World Bank (data.worldbank.org)

${ }^{1}$ Based on current Local Currency Unit (LCU), i.e., current JPY.

${ }^{2}$ Based on constant LCU, i.e., constant JPY.

${ }^{3}$ Based on current USD.

${ }^{4}$ Based on constant USD.

${ }^{5}$ Annual data in 1989-2019.

The term "Japanification" refers to such a Japan-like economic condition of long-term slow growth and low inflation. Not only has it been an enduring dilemma of the Japanese economy, but also it is becoming a concern of the European economy (Mackintosh, 2019). Obviously, Japan's economic difficulties contribute to its poor stock performance in the long run. The relationship between Japan's economic variables and its stock performance has been examined and confirmed by a number of research articles such as Mun (2012), Aono and Iwaisako (2013), and Ramdhan, Yousop, Ahmad, and Abdullah (2018).

\section{Negative Economic Aspects}

Japan's economic growth is very slow in the past 30 years. First, as Panel A of Table 3 reports, its annual nominal GDP growth rate across the entire three decades is $0.92 \%$ in JPY and $1.71 \%$ in USD, much lower than $4.55 \%$ of the US. Likewise, Japan's annual real GDP growth rate is $1.09 \%$ in JPY or USD, lower than $2.46 \%$ of the US. Second, in each of the three decades, every growth measure of Japan is lower than that of the US. Third, Japan's slow economic growth alone seems not enough to explain its poor stock performance. In 1989-2019, Japan's nominal GDP growth rates (0.92\% in JPY and $1.71 \%$ in USD) are higher than its annual stock index returns $(-1.65 \%$ in JPY and $-0.91 \%$ in USD) while the US's nominal GDP growth rate (4.55\% in USD) is lower than its annual stock index return (7.66\% in USD).

Besides a very modest GDP growth, other economic problems also haunt Japan's stock performance such as low inflation and interest rates, high public debt and fiscal deficit, an aging workforce, mild productivity and innovation, and the hollowing out of domestic industry due to globalization.

First, Japan's inflation rates stay below the usual target (2\%) most of the time in 1989-2019 and deflation (negative inflation) happens often. Its mean of annual inflation rate based on a GDP deflator is $-0.17 \%$, lower than $2.04 \%$ for the US; in addition, its mean of annual inflation rate based on consumer prices is $0.47 \%$, lower than $2.45 \%$ for the US (see Panel B of Table 3). Furthermore, Japan's government bonds pay low or even negative yields to investors. Its mean 10-year government bond yield in 1989-2019 is $1.16 \%$, much lower than $4.32 \%$ for the US (see Panel B of Table 3 ).

Second, Japan has about $\$ 10$ trillion government debt and its public-debt-to-GDP ratio is roughly $240 \%$ as compared with the US's 106\% (Fujikawa and Narioka, 2019). The mean of government debt as percentage of GDP in 1989-2019 is 134\% for Japan, much higher than 77\% for the US (see Panel B of Table 3). Besides, Japan's large fiscal deficits may result from its series of stimulus fiscal packages under "stock price targeting" in the 1990s and 2000s (Fukuda and Yamada, 2011).

Third, Japan has a low fertility rate and its population has declined for years, and is expected to keep falling. The ratio of working-age population to dependent population is 1.0 in Japan as compared with 1.5 globally (Glassman, 2018). The mean annual population growth rate in 1989-2019 is $0.08 \%$ for Japan, lower than $0.99 \%$ for the US (see Panel B of Table 3). 
Fourth, Japan's labor productivity is $71 \%$ of the US's; its rate of new company creation is only half of the US and Japan ranks last among 24 developed nations in terms of entrepreneurial activity (Rattner, 2013). In addition, its modest growth of total factor productivity (TFP) in the 1990s leads to its low capital utilization rates, which explains its low growth of output (Miyazawa, 2012).

Fifth, Japan's pursuit of globalization by its large transnationals diverts new investment from its own industrial regions to foreign countries and encourages these transnationals to outsource their production overseas, hurting the demand for intermediate goods supplied by Japan's small firms (Cowling and Tomlinson, 2000).

\section{Positive Economic Aspect}

Notwithstanding the above challenges, there is one bright spot though for Japan's economy. Its unemployment rate stays low in the past 30 years, ranging from $2.09 \%$ to $5.36 \%$ while its mean is $3.75 \%$ vs. 5.84\% for the US (see Panel B of Table 3). Even during the global recession (January 2008 to November 2011), Japan's unemployment rate lingers between $4-6 \%$, much lower than $5-10 \%$ of the US (Allen, Carletti, and Grinstein, 2018). In the short-term, labor protection laws in Japan make it difficult to significantly cut production costs during the recession, causing large dents in profit, cash cushions, and stock returns. However, in the long-term, steady employment helps Japan keep its society safe and balanced.

\section{Recent Economic Conditions}

Japan's most recent economic developments show some positive results, which are in line with its decent stock performance in the most recent decade. "Abenomics," particularly its expansionary monetary policy, has weakened the yen, raised stock prices, and generated a positive inflation since 2012, though its real effects have been modest (Hausman and Wieland, 2015). Japan's negative interest rate policy exerts some positive effects on Asian stock prices (Fukuda, 2018). New gains in productivity associated with a move to a "cashless society" and a labor force expansion following an influx of immigrants help accelerate Japan's economic growth (Curran, 2018). Japan's labor productivity growth has outstripped its G-7 peers since 2010 and its real GDP per member of the working-age population has risen faster than that of any G7 economy since 2007 (Bird, 2019b). In spite of the positive trend, nevertheless, several increases in sales tax have led to economic hits (Bird, 2019c, 2020).

\section{Corporate Governance}

Summary of Corporate Governance

Corporate governance deals with mechanisms that ensure a return for investors in corporations. In the short-term, strong governance may not be associated with high stock returns; in the long-term, however, the payoff to strong governance may exist for stock investors (Damodaran, 2014). Relative to the US and the UK, Japan has weak corporate governance, which may contribute to its poor stock performance in the past three decades. The weak governance of Japanese corporations is reflected in the following areas: weak legal protections and low governance ratings, the all-stakeholders-centered objective, and the insidersdominated and cross-holding ownership structure.

\section{Weak Legal Protections and Low Governance Ratings}

Japan has weaker legal protections for stockholders and lower governance ratings than the US and the UK. In a measurement by La Porta, Lopez-de-Silanes, Shleifer, and Vishny (1998, 2000a), English Law or Common Law countries (such as the US and the UK) protect both stockholders and creditors the most, French civil law countries (such as France) the least, and German civil law countries (such as Germany and Japan) and Scandinavian civil law countries (such as Norway) stand somewhere in between. In the measurement of shareholder rights, Japan has weaker scores than the US and the UK (La Porta, Lopez-deSilanes, Shleifer, and Vishny, 1998). In terms of the S\&P transparency and disclosure ratings and the FTSE ISS corporate governance ratings, Japan also has lower mean scores (54.15 and 35.95) than the UK (71.36 and 37.58) according to Doidge, Karolyi, and Stultz (2007). Finally, when it comes to the GMI rating, Japan has a lower ranking score (3.3) than the UK (7.6) and the US (7.16). ${ }^{1}$ 


\section{All-Stakeholders-Centered Objective}

Japanese corporations establish an all-stakeholders-centered objective. Unlike managers of the UK and the US, Japanese counterparts do not have a fiduciary duty to stockholders; rather, the interests of all stakeholders (in particular employees) matter in the corporate objective (Allen, Carletti, and Grinstein, 2018). In the survey by Diamond (2011), a majority of Japanese firms considers employees and customers as the most important stakeholders, and only a minority of them considers investors as highly important. As the survey by Yoshimori (1995) shows, $97.1 \%$ of Japanese managers agree that a company exists for all stakeholders (vs. shareholder priority), whereas $24.4 \%$ of US managers think so; likewise, $97.1 \%$ of Japanese managers agree that maintaining stable employment is more important than maintaining dividend payments, whereas $10.8 \%$ of US managers concur.

\section{Insiders-Dominated and Cross-Holding Ownership Structure}

Historically, Japanese corporations are known for their insiders-dominated and cross-holding ownership structure as compared to the diverse and market-orientated ownership structure of the US and the UK. In such a relationship-based structure of Japan, corporations are primarily financed and monitored by insiders (financial institutions and other corporations), and they may cross-hold stock shares among themselves. As Franks, Mayer, and Miyajima (2014) report, the percentage of Japanese stock shares held by insiders is very high in 1990 (61.6\%); even after some unwinding, it is still quite high in 2009 (38.3\%). On the contrary, in the market-based structure of the US and the UK, corporations are financed by large numbers of outside investors, and takeovers play a key disciplinary role.

Japan's relationship-based structure does show some positive implications, especially in the 1980s. As La Porta, Lopez-de-Silanes, Shleifer, and Vishny (2000a) point out, far-sighted banks enable firms to focus on long-term investment decisions, deliver capital to firms facing liquidity shortfalls, and replace disruptive takeovers with bank intervention. Prowse (1992) shows that in the mid-1980s, Japan's stock ownership was concentrated in financial institutions and this concentration was positively related to the stock returns for independent firms; however, this was not the case for firms that are members of corporate groups (keiretsu). Kang, Shivdasani, and Yamada (2000) find that in 1977-1993, close ties with informed creditors such as banks facilitated acquisitions that enhanced shareholder wealth.

However, since the early 1990s, negative implications have become the main theme for Japan's relationship-based structure. First, in the 1990s and as the Japanese economy started to collapse, banks perpetrated soft budget constraints, over-lent to declining firms, and colluded with managers to deter external threats to their control (La Porta, Lopez-de-Silanes, Shleifer, and Vishny, 2000a).

Second, at low levels of bank ownership, Tobin's $q$ falls with increased bank equity stakes. Given that banks' stakes as creditors are typically substantial, their moderate equity stakes may give them considerable voice in corporate governance without significantly aligning their interests with those of shareholders, which could lower the valuation for public shareholders (Morck, Nakamura, and Shivdasani, 2000).

Third, the cross-shareholder and stable-shareholder ownership leads to the strength of managers' defense against market disciplinary power. When managers are insulated from the disciplinary power of the stock market, they avoid making difficult decisions such as large investments and business restructures, which may lead to reduced growth in the future. However, when managers are closely monitored by institutional investors and independent directors, they tend to be active in making difficult decisions for corporate growth (Ikeda, Inoue, and Watanabe, 2018).

Fourth, insiders-dominated governance may allow for the expropriation of minority stockholders. For example, the Japanese subsidiaries in which the parent firm retains $20-50 \%$ ownership tend to be listed publicly at overvalued prices; afterwards, the minority stockholders of the subsidiaries are inclined to experience poor stock returns (Chernenko, Foley, and Greenwood, 2012).

Fifth, the insiders-dominated governance tends to be linked to the inactive M\&A market of Japan. With the relationship-based corporate culture, shareholders seldom confront management. The market for corporate control is very thin and M\&A (i.e., acquisition of majority stake) is not a clear exit strategy for activist investors. With over 4,000 listed firms, there are only 45 M\&A deals in 2000 and 98 in 2008. In addition, firms targeted by activists adopt "poison pills," leading to a subsequent drop in investor activism 
(Hamao and Matos, 2018). Moreover, mergers in Japan seem not to create wealth for shareholders of target firms and appear to be driven chiefly by creditor concerns. When merging firms share a common main bank the merger gains are lower (Mehrotra, Schaik, Spronk, and Steenbeek, 2011).

\section{Recent Changes in Corporate Governance}

In recent years, Japan's corporate governance seems by and large to have become stronger. First, the Japanese government has conducted reforms to improve corporate governance since the mid- to late-1990s, leading to the approval of stock options and share repurchases, the decrease in corporate restructuring costs, the adoption of internationally accepted accounting standards, the reduction in the size of boards of directors, and the increase in the number of outside directors (Kato, Li, and Skinner, 2017). Second, outside ownership, i.e., the percentage of shares held by institutional investors, securities houses, foreigners, and individuals, has risen from 38.4\% in 1990 to 61.7\% in 2009 (Franks, Mayer, and Miyajima, 2014). Third, the monitoring and restructuring function of banks declines. In 1981-2010, even though the ratio of distressed firms among all listed has not declined, the incidence of restructuring by such firms has become less frequent after the 1990s, signaling a decline in the governance and rescue role of the main bank (Hoshi, Koibuchi, and Schaede, 2018). Fourth, in 1990-2013, the presence of a main bank has been weakened, the ownership of institutional investors has rapidly increased, and independent outside directors have been introduced in many firms (Miyajima, Ogawa, and Saito, 2018). In particular, foreign institutional investors strengthen the executive turnover sensitivity to return on equity (ROE), highlighting the disciplinary role played by outside investors.

Given the above positive changes, today, Japan's banks and government still exert important influences on stocks. As Miyajima, Ogawa, and Saito (2018) report, strong ties with main banks increase the executive turnover sensitivity to ROE in the more recent period, suggesting that main banks continue to perform a disciplinary role. According to Bird (2019a), Japan's central bank owns more than three-quarters of the country's entire equity ETFs, hinting a state involvement in the stock market. Warnock (2016) documents that Japan's government has postponed a plan to let its public pension fund buy and sell stocks directly due to concerns that the move could lead to excessive state influence on the market.

\section{Corporate Financial Policies}

Summary of Corporate Financial Policies

Corporate financial policies cover financial vs. operating asset investments, debt vs. equity financing, and dividend distributions. Compared with the US, Japanese corporations are inclined to hold more financial assets, borrow more debt, pay less dividends, and have less stock buybacks. Table 4 shows the financial assets for Japanese and US firms in 2011-2017. The Japanese results are based on the nonfinancial firms in the MSCI-Japan Index and the US results are based on the non-financial firms in the S\&P 500 Index. We obtain annual data during the sample period and calculate the average ratio across six years for each firm. Table 5 displays the debt and dividend for Japan and the US in 1999-2019. The statistics of Japan are based on the annual aggregate data of EWJ (iShares MSCI-Japan ETF) and those of the US are based on the annual aggregate data of SPY (SPDR S\&P 500 ETF). 
TABLE 4

CORPORATE FINANCIAL POLICIES: FINANCIAL ASSETS IN 2011-2017

\begin{tabular}{|l|c|c|c|c|}
\hline & $\begin{array}{c}\text { Cash \& Short-Term } \\
\text { Investments as \% of } \\
\text { Total Assets }^{1}\end{array}$ & $\begin{array}{c}\text { Total Investments \& } \\
\text { Advances as \% of } \\
\text { Total Assets }\end{array}$ & $\begin{array}{c}\text { Financial Assets } \\
\text { as \% of Total Assets }\end{array}$ & $\begin{array}{c}\text { Number } \\
\text { of firms }^{\text {\% }}\end{array}$ \\
\hline Japanese firms & & & & 266 \\
Mean & $17.72 \%$ & $10.66 \%$ & $15.60 \%$ & \\
S.D. & $13.80 \%$ & $8.23 \%$ & $25.10 \%$ & \\
Median & $14.47 \%$ & $8.84 \%$ & $16.97 \%$ & \\
\hline US firms & & & $15.25 \%$ & \\
Mean & $13.47 \%$ & $3.49 \%$ & $12.12 \%$ & \\
S.D. & $13.21 \%$ & $6.28 \%$ & & \\
Median & $9.01 \%$ & $1.05 \%$ & $9.33^{*}$ & \\
\hline Difference & $3.96^{*}$ & $12.07^{*}$ & \\
t-value & &
\end{tabular}

Source: Factset

${ }^{1}$ We obtain annual data in 2011-2017. We calculate the average ratio across six years for each firm.

${ }^{2}$ Financial Assets are the sum of Cash \& Short-Term Investments and Total Investments \& Advances.

${ }^{3}$ The Japanese firms are the non-financial firms in the MSCI-Japan Index.

${ }^{4}$ The US firms are the non-financial firms in the S\&P 500 Index.

${ }^{*}$ Significance at the $5 \%$ level.

TABLE 5

CORPORATE FINANCIAL POLICIES: DEBT AND DIVIDEND IN 1999-2019

Panel A. Sub-period: 1999-2009

\begin{tabular}{|l|c|c|}
\hline & $\begin{array}{c}\text { Japan: } \\
\text { MSCI-Japan Index }\end{array}$ & $\begin{array}{c}\text { US: } \\
\text { S\&P 500 Index }\end{array}$ \\
\hline Total Debt/Total Assets: mean & $33.08 \%$ & $30.50 \%$ \\
Total Debt/Total Assets: median & $32.90 \%$ & $30.28 \%$ \\
Total Debt/Total Assets: max & $40.11 \%$ & $33.72 \%$ \\
Total Debt/Total Assets: min & $27.51 \%$ & $27.05 \%$ \\
\hline Total Debt/Total Capital: mean & $50.25 \%$ & $47.10 \%$ \\
Total Debt/Total Capital: median & $49.66 \%$ & $46.64 \%$ \\
Total Debt/Total Capital: max & $59.27 \%$ & $50.90 \%$ \\
Total Debt/Total Capital: min & $43.07 \%$ & $43.13 \%$ \\
\hline Interest coverage: mean & 7.44 & 5.66 \\
Interest coverage: median & 7.92 & 6.00 \\
Interest coverage: max & 11.78 & 7.12 \\
Interest coverage: min & 3.02 & 3.87 \\
\hline Dividend payout ratio: mean $^{3}$ & $29.24 \%$ & $32.79 \%$ \\
Dividend payout ratio: median $^{3}$ & $23.11 \%$ & $30.25 \%$ \\
Dividend payout ratio: max $^{3}$ & $70.94 \%$ & $39.65 \%$ \\
Dividend payout ratio: min $^{3}$ & $19.46 \%$ & $28.22 \%$ \\
\hline Dividend yield: mean & $1.22 \%$ & $1.80 \%$ \\
Dividend yield: median & $1.02 \%$ & $1.72 \%$ \\
Dividend yield: max & $2.46 \%$ & $3.18 \%$ \\
Dividend yield: min & $0.64 \%$ & $1.20 \%$ \\
\hline
\end{tabular}


Panel B. Sub-period: 2009-2019

\begin{tabular}{|l|c|c|}
\hline & $\begin{array}{c}\text { Japan: } \\
\text { MSCI-Japan Index }\end{array}$ & $\begin{array}{c}\text { US: } \\
\text { S\&P 500 Index }\end{array}$ \\
\hline Total Debt/Total Assets: mean & $31.07 \%$ & $30.20 \%$ \\
Total Debt/Total Assets: median & $31.04 \%$ & $30.21 \%$ \\
Total Debt/Total Assets: max & $33.11 \%$ & $32.84 \%$ \\
Total Debt/Total Assets: min & $28.21 \%$ & $27.62 \%$ \\
\hline Total Debt/Total Capital: mean & $46.23 \%$ & $45.53 \%$ \\
Total Debt/Total Capital: median & $46.21 \%$ & $45.34 \%$ \\
Total Debt/Total Capital: max & $49.75 \%$ & $48.68 \%$ \\
Total Debt/Total Capital: min & $41.81 \%$ & $42.10 \%$ \\
\hline Interest coverage: mean & 12.15 & 7.86 \\
Interest coverage: median & 12.72 & 7.76 \\
Interest coverage: max & 15.82 & 9.11 \\
Interest coverage: min & 8.42 & 6.88 \\
\hline Dividend payout ratio: mean & $32.41 \%$ & $33.88 \%$ \\
Dividend payout ratio: median & $31.65 \%$ & $34.01 \%$ \\
Dividend payout ratio: max & $46.10 \%$ & $40.95 \%$ \\
Dividend payout ratio: min & $26.87 \%$ & $26.30 \%$ \\
\hline Dividend yield: mean & $2.09 \%$ & $1.93 \%$ \\
Dividend yield: median & $2.02 \%$ & $1.94 \%$ \\
Dividend yield: max & $2.58 \%$ & $2.08 \%$ \\
Dividend yield: min & $1.73 \%$ & $1.75 \%$ \\
\hline
\end{tabular}

Source: Factset

${ }^{1}$ Based on annual aggregate data of EWJ (iShares MSCI-Japan ETF).

${ }^{2}$ Based on annual aggregate data of SPY (SPDR S\&P 500 ETF).

${ }^{3}$ The 2009 observations are outliers for both indexes and are excluded.

The corporate financial policies of Japan (excess financial assets, high debt, and low dividend \& share repurchase) primarily result from its bank-centered governance system and its weak legal protection for minority stockholders. These policies generally exert negative effects on stock returns over the long run.

\section{Excess Financial Assets}

Financial assets belong to non-operating assets and consist of short-term financial assets (such as cash and short-term investments) and long-term financial assets (such as equity investments in other firms and long-term financial securities). The motives for holding financial assets contain precaution or safety, future capital investments, and strategic alliance. Nonetheless, excessively high levels of financial assets may reflect under-investments in operating assets currently, causing inadequate returns for stockholders in the future. Compared with the US, Japanese corporations hold far more financial assets, which is a situation regarded as an obstacle for long-term value enhancement.

In respect of short-term financial assets, many studies, such as Pinkowitz and Williamson (2001), Dittmar, Mahrt-Smith, and Servaes (2003), Khurana, Martin, and Pereira (2006), Riddick and Whited (2009), and Azar, Kagy, and Schmalz (2016), document higher cash holding for Japanese firms than US firms. Due to the reforms of corporate governance in the mid- to late-1990s, the cash holding of Japanese firms has reduced from the peak of 1980s (Kato, Li, and Skinner, 2017); however, it has risen again since the 2008-2009 crisis (Aoyagi and Ganelli, 2017). Based on the recent data of 2011-2017, Cash \& ShortTerm Investments, as a measure of short-term financial assets, are on average $17.72 \%$ of Total Assets for Japan, significantly higher than $13.47 \%$ for the US (see Table 4). 
Higher cash holding can lead to three negative aspects: more agency conflicts (Luo and Hachiya, 2005; Aoyagi and Ganelli, 2017), lower capital expenditure (Dittmar, Mahrt-Smith, and Servaes, 2003), and lower valuation (Luo and Hachiya, 2005; Khurana, Martin, and Pereira, 2006; Riddick and Whited, 2009). Nevertheless, higher cash holding can also relate to one positive aspect: lower cost of carry (Azar, Kagy, and Schmalz, 2016).

Besides short-term financial assets, Japanese firms also hold a large amount of long-term financial assets. Despite a gradual unwinding of cross-holdings since 1990, the feature persists up to today. Based on the data of 2011-2017, Total Investments \& Advances as a measure of long-term financial assets, on average, are $10.66 \%$ of Total Assets for Japan, significantly higher than $3.49 \%$ for the US (see Table 4 ). Likewise, Financial Assets, i.e., the sum of Cash \& Short-Term Investments and Total Investments \& Advances are, on average, $28.37 \%$ of Total Assets for Japan, significantly higher than $16.97 \%$ for the US (see Table 4).

Overall, if the excess financial assets of Japanese firms could be utilized in organic expansions of operating assets, acquisitions of other firms, regular cash dividend payments, share repurchases, etc., considerable value-driving forces might be unlocked for stock investors.

\section{High Debt}

The debt vs. equity financing policies may be associated with macroeconomic environment, corporate governance practices, legal protection for investors, tax system, firm-specific features, etc. Japanese firms used to have high debt ratios, which might denote high financial leverage risk; however, the phenomenon has faded away in recent years.

Based on the data of 1998, the book leverage (total debts divided by total assets) is $29.8 \%$ for Japan, higher than 23.6\% for the US and 16.9\% for the UK (Dittmar, Mahrt-Smith, and Servaes, 2003). Based on the data of $1987-2000$, the book leverage is $30.1 \%$ for Japan, higher than $27.4 \%$ for the US and $17.9 \%$ for the UK (Antoniou, Guney, and Paudyal, 2008). Panel A of Table 5 shows that based on the data of 19992009, Japan has higher Total Debt/Total Assets ratio (33.08\%) and higher Total Debt/Total Capital ratio $(50.25 \%)$ than the US (30.50\% and $47.10 \%$, respectively).

In the most recent decade (2009-2019), Japan's debt ratios (31.07\% and 46.23\%) turn lower and draw close to those of the US (30.20\% and $45.53 \%$ ), indicating an improvement in capital structure (see Panel B of Table 5). Moreover, the percent of equity firms (firms with $0 \%$ to $5 \%$ debt ratio) has grown from $7.5 \%$ in 1990 to $28.3 \%$ in 2014 (Khoo and Durand, 2017).

It is necessary to point out that Japan's interest-paying capability seems strong irrespective of its debt ratio. As Table 5 presents, Japan's interest coverage ratios in both 1999-2009 and 2009-2019 periods (7.44\% and $12.15 \%)$ are higher than those of the US (5.66\% and $7.86 \%)$, implying a protection for creditors such as banks.

\section{Low Dividend \& Share Repurchase}

Both dividend yield and share repurchase influence stock returns (Chen, 2012; L'Her, Masmoudi, and Krishnamoorthy, 2018). Japanese firms used to distribute low dividends and have no practice of share repurchase, which might be against the interest of minority stockholders. In recent years, however, they have shifted to improved dividends and boosted share repurchase.

First, we discuss evidence on the regular cash dividend. Ide (1996) shows that in 1985-1990, the dividend payout ratio is 33\% for Japan, lower than $45 \%$ for the US. Dewenter and Warther (1998) point out that compared with US firms, Japanese firms are less reluctant to omit and cut dividends based on data from 1982 to 1993. La Porta, Lopez-de-Silanes, Shleifer, and Vishny (2000b) report that based on the data of 1994 , the Dividends/Sales ratio is $0.72 \%$ for Japan, lower than $0.95 \%$ for the US and $1.89 \%$ for the UK. Pinkowitz, Williamson, and Stulz (2007) document that based on the data of 1988-1998, the Dividends/Total Assets ratio is $0.5 \%$ for Japan, lower than $0.8 \%$ for the US and $2.4 \%$ for the UK. Kato, Li, and Skinner (2017) show that in 1990-2011, the median dividends/assets ratio is $0.6 \%$ for Japan, lower than $1.8 \%$ for the US. L'Her, Masmoudi, and Krishnamoorthy (2018) find that in 1997-2017, the dividend yield is $1.5 \%$ for Japan, lower than $1.9 \%$ for the US; and the net buyback is $-2.3 \%$ for Japan, lower than 
$-1.8 \%$ for the US. ${ }^{2}$ Panel A of Table 5 presents that in 1999-2009, Japan has a lower dividend payout ratio (29.24\%) and lower dividend yield (1.22\%) than the US (32.79\% and $1.80 \%$, respectively). But in the most recent decade (2009-2019), Japan's payout ratio (32.41\%) and dividend yield (2.09\%) turn higher and become similar to those of the US (33.88\% and $1.93 \%$, respectively), suggesting a progress in investor protection (see Panel B of Table 5).

Second, we illustrate findings on share repurchase. According to Tong and Bremer (2016): share repurchase in Japan has been effectively permitted without constraint since 2001; firms whose dominant owners are other members of the firm's industrial group are less likely to repurchase; bank ownership has mixed implications for repurchases; and firms having foreign and individual ownership are more likely to repurchase stock. As Kato, Li, and Skinner (2017) point out, the fraction of Japanese firms that repurchases their own stock shares increases from close to $0 \%$ in 1997 to around $10 \%$ in $1999-2001$ and then fluctuates between $14 \%$ and $30 \%$ in $2002-2011$.

\section{Corporate Financial Performance}

Summary of Corporate Financial Performance

Return and growth are the main value drivers for stockholders (Koller, Goedhart, and Wessels, 2015). Generally speaking, Japanese firms have experienced low return and slow growth in the past three decades, leading to inadequate value creation.

Table 6 provides the profitability measures for Japan and the US in 1999-2019, including the net margin and ROE. The statistics about Japan are based on the annual aggregate data of EWJ (iShares MSCI-Japan ETF) and the statistics about the US are based on the annual aggregate data of SPY (SPDR S\&P 500 ETF).

\section{TABLE 6}

\section{CORPORATE FINANCIAL PERFORMANCE: PROFITABILITY IN 1999-2019}

Panel A. Sub-period: 1999-2009

\begin{tabular}{|l|c|c|}
\hline & $\begin{array}{c}\text { Japan: } \\
\text { MSCI-Japan Index }\end{array}$ & $\begin{array}{c}\text { US: } \\
\text { S\&P 500 Index }\end{array}$ \\
\hline Net margin: mean & $2.99 \%$ & $7.35 \%$ \\
Net margin: median & $3.04 \%$ & $7.59 \%$ \\
Net margin: max & $4.92 \%$ & $9.06 \%$ \\
Net margin: min & $0.63 \%$ & $5.37 \%$ \\
\hline ROE: mean & $6.84 \%$ & $14.31 \%$ \\
ROE: median & $7.71 \%$ & $14.97 \%$ \\
ROE: $\max$ & $10.28 \%$ & $17.15 \%$ \\
ROE: $\min$ & $1.26 \%$ & $9.07 \%$ \\
\hline
\end{tabular}

Panel B. Sub-period: 2009-2019

\begin{tabular}{|l|c|c|}
\hline & Japan: & US: \\
& MSCI-Japan Index & S\&P 500 Index \\
\hline Net margin: mean & $4.87 \%$ & $9.85 \%$ \\
Net margin: median & $5.11 \%$ & $9.69 \%$ \\
Net margin: max & $7.05 \%$ & $11.03 \%$ \\
Net margin: min & $2.62 \%$ & $8.81 \%$ \\
\hline ROE: mean & $8.29 \%$ & $15.25 \%$ \\
ROE: median & $8.72 \%$ & $15.34 \%$ \\
ROE: $\max$ & $10.75 \%$ & $17.03 \%$ \\
ROE: $\min$ & $5.32 \%$ & $13.72 \%$ \\
\hline
\end{tabular}

Source: Factset

${ }^{1}$ Based on annual aggregate data of EWJ (iShares MSCI-Japan ETF).

${ }^{2}$ Based on annual aggregate data of SPY (SPDR S\&P 500 ETF). 
Table 7 presents the growth measures of 1989-2019 for Japan and the US. In Panel A, the annual growth rate of EPS is the growth measure. The EPS of an index is calculated as the index level divided by its concurrent $\mathrm{P} / \mathrm{E}$ ratio and the annual growth rate of EPS is calculated as the geometric mean of the percentage change in EPS levels from 1989 to 2019. In Panel B, the growth measures contain internal growth rate, annual revenue growth rate, annual net income growth rate, and annual dividend growth rate. The statistics about Japan are based on the annual aggregate data of EWJ (iShares MSCI-Japan ETF), and the statistics about the US are based on the annual aggregate data of SPY (SPDR S\&P 500 ETF).

TABLE 7

CORPORATE FINANCIAL PERFORMANCE: GROWTH IN 1989-2019

Panel A. Annual EPS growth rate (geometric mean) in 1989-2019

\begin{tabular}{|c|c|c|c|c|}
\hline $\begin{array}{c}\text { Japan: } \\
\text { Tokyo Stock } \\
\text { Exchange } 1^{\text {st }} \\
\text { Section (JPY) }\end{array}$ & $\begin{array}{c}\text { Japan: } \\
\text { Tokyo Stock } \\
\text { Exchange } 1^{\text {st }} \\
\text { Section (USD) }\end{array}$ & $\begin{array}{c}\text { Japan: } \\
\text { Nikkei } 225 \text { Index } \\
(\text { JPY })^{3}\end{array}$ & $\begin{array}{c}\text { Japan: } \\
\text { Nikkei } 225 \text { Index } \\
(\text { USD })^{4}\end{array}$ & $\begin{array}{c}\text { US: } \\
\text { S\&P 500 Index } \\
(\text { USD })^{5}\end{array}$ \\
\hline $2.04 \%$ & $2.80 \%$ & $2.00 \%$ & $2.76 \%$ & $6.22 \%$ \\
\hline
\end{tabular}

Panel B: Sub-periods ${ }^{6}$

\begin{tabular}{|l|c|c|}
\hline & $\begin{array}{c}\text { Japan: } \\
\text { MSCI-Japan Index } \\
\text { (USD) }\end{array}$ & $\begin{array}{c}\text { US: } \\
\text { S\&P 500 Index } \\
\text { (USD) }\end{array}$ \\
\hline Sub-period: 1999-2009 & $4.84 \%$ & $9.62 \%$ \\
Internal growth rate & $1.93 \%$ & $6.45 \%$ \\
Annual revenue growth rate (geometric mean) & $1.97 \%$ & $0.15 \%$ \\
Annual net income growth rate (geometric mean) & $12.94 \%$ & $7.67 \%$ \\
Annual dividend growth rate (geometric mean) & & \\
\hline Sub-period: $2009-2019$ & $5.60 \%$ & $10.08 \%$ \\
Internal growth rate & $2.08 \%$ & $4.25 \%$ \\
Annual revenue growth rate (geometric mean) & $25.18 \%$ & $10.59 \%$ \\
Annual net income growth rate (geometric mean) & $8.06 \%$ & $8.97 \%$ \\
Annual dividend growth rate (geometric mean) & & \\
\hline
\end{tabular}

Sources: Factset, World Bank (data.worldbank.org), and other sources.

${ }^{1}$ Based on data from CEIC's website (www.ceicdata.com/en/indicator/japan/pe-ratio).

${ }^{2}$ The EPS of the TSE 1st Section in USD is calculated as the EPS of the TSE 1st Section in JPY divided by the concurrent official exchange rate of JPY/USD.

${ }^{3}$ Based on data from Nikkei's website (indexes.nikkei.co.jp/en/nkave/archives/data) and Hardy (1993).

${ }^{4}$ The EPS of the Nikkei 225 Index in USD is calculated as the EPS of the Nikkei 225 Index in JPY divided by the concurrent official exchange rate of JPY/USD.

${ }^{5}$ Based on data from Shiller's website (www.econ.yale.edu/ shiller/data.htm).

${ }^{6}$ Based on data from Factset.

${ }^{7}$ Based on annual aggregate data of EWJ (iShares MSCI-Japan ETF). Variables are denominated in USD.

${ }^{8}$ Based on annual aggregate data of SPY (SPDR S\&P 500 ETF). Variables are denominated in USD.

${ }^{9}$ Calculated as the multiplication of ROE and ( 1 - dividend payout ratio).

\section{Low Profitability}

Japanese firms have consistently generated lower profitability than US firms since the 1980s. First, during 1981-1990, Japan's average ROE is $8.4 \%$, lower than the US $14.5 \%$ (Ide, 1996). Second, based on the data of 2004-2013, Japan's ROE is about 7\%, lower than the US's 15\% and UK's 12\% (Yanagi, 2018). Third, in 1999-2009, Japan's average net margin is $2.99 \%$ and average ROE is $6.84 \%$, lower than the US 
$7.35 \%$ and $14.31 \%$, respectively (see Panel A of Table 6). Fourth, in the most recent decade (2009-2019), Japan's average net margin is $4.87 \%$ and average ROE is $8.29 \%$, lower than the US $9.85 \%$ and $15.25 \%$, respectively (see Panel B of Table 6). Therefore, Yanagi (2018) argues that boosting the ROE of Japanese firms is the remedy for value creation.

Over time, admittedly, Japanese firms have paid more attention to profitability and even improved it. Between 1998 and 2006, large Japanese companies reposition into innovative and high-margin sectors and shift from the post-war priority on sales and market share toward a new focus on profitability (Schaede, 2012). In recent years, there is a cultural shift putting a new emphasis on ROE, which for Japanese stocks has increased to almost 10\% today from less than 5\% before Prime Minister Shinzo Abe won the 2012 election (Curran, 2018).

\section{Slow Growth of EPS and Revenues}

Over the past three decades, Japanese firms grow at a slower pace than US firms. As Panel A of Table 7 presents, in 1989-2019, the annual EPS growth rate is 2.80\% for the Tokyo Stock Exchange 1st Section in USD and $2.76 \%$ for the Nikkei 225 Index in USD, much lower than $6.22 \%$ for the S\&P 500 Index in USD. However, it is noteworthy that Japan's EPS growth rate in USD $(2.76 \%)$ is higher than its annual stock index return in USD $(-0.91 \%)$ while the US's EPS growth rate $(6.22 \%)$ is lower than its annual stock index return (7.66\%). The comparison indicates that Japan's slow EPS growth is not enough to explain its poor stock performance.

In sub-periods, some growth measures of Japanese firms are persistently lower than those of US firms. As Ide (1996) reports, in 1985-1990, the internal growth rate, calculated as the multiplication of ROE and retention ratio (i.e., 1 - dividend payout ratio), is $4.9 \%$ for Japan, lower than $8.9 \%$ for the US. As Panel B of Table 7 shows, Japan's internal growth rate is 4.84\% in 1999-2009 and 5.60\% in 2009-2019 compared with the US at $9.62 \%$ and $10.08 \%$, respectively. Moreover, Japan's annual revenue growth rate is $1.93 \%$ in 1999-2009 and 2.08\% in 2009-2019 compared with the US $6.45 \%$ and $4.25 \%$, respectively.

Despite the overall slow growth, the earnings and dividends of Japanese firms grow at a decent pace in recent years. Kato, Li, and Skinner (2017) report that aggregate dividends (repurchases and regular cash dividends) grow at a compound annual real rate of $11.7 \%$ from 1999 to 2008. L'Her, Masmoudi, and Krishnamoorthy (2018) document that in 1997-2017 the real dividend per share growth is 5.7\% for Japan, higher than 3.8\% for the US. Panel B of Table 7 shows that the annual net income growth rate and the annual dividend growth rate of Japan are higher than or similar to those of the US in the 1999-2009 and 2009-2019 periods, respectively. Such achievements of Japanese firms mainly result from their improvement of profitability in recent years given their still sluggish growth of revenues.

\section{Relative Valuation}

Summary of Relative Valuation

The above sections have discussed Japan's economic and corporate issues. Beyond those, relative valuation measures, such as price-to-earnings ratio $(\mathrm{P} / \mathrm{E})$ and price-to-book ratio $(\mathrm{P} / \mathrm{B})$ also play an important role in stock performance, and convey the market perception of business fundamentals. An expansion of these measures leads to a positive effect on stock price, whereas a contraction leads to a negative effect. From 1989 to 2019, the relative valuation measures of Japan have reduced substantially, contributing to its poor stock performance.

Moreover, book-to-market ratio (the inverse of price-to-book ratio), or HML (return difference between high and low book-to-market portfolios), is an important factor in asset pricing models. A number of studies have tested the Japanese stock markets in this regard, including Chan, Hamao, and Lakonishok (1991), Chan, Hamao, and Lakonishok (1993), Fama and French (2012), Fukuta and Yamane (2015), and Kubota and Takehara (2018). They demonstrate that book-to-market ratio, or HML, exerts significant effect on Japanese stock returns. 


\section{Contraction of Relative Valuation}

The relative valuation measures of Japanese stocks were awfully high in 1989 but they contracted considerably during the early 1990s and stayed low afterwards. For example, based on the data of 1995, Tobin's $q$ is 1.33 for Japan, lower than 3.08 for the US and 1.72 for the UK (La Porta, Lopez-de-Silanes, Shleifer, and Vishny, 2002).

Table 8 reports four relative valuation measures for Japan and the US in 1989 and 2019, including market capitalization as \% of GDP, cyclically adjusted PE (CAPE), P/E, and P/B. As Panel A shows, Japan's market capitalization as \% of GDP reduces from 139\% in 1989 to $122 \%$ in 2019 . While its 1989 measure $(139 \%)$ is much higher than that of the US (60\%), its 2019 measure $(122 \%)$ is lower than that of the US (178\%). As Panel B shows, Japan's CAPE ratio declines from 90.00 in 1989 to 22.09 in 2019. While its 1989 measure (90.00) is much higher than that of the US (17.65), its 2019 measure (22.09) is lower than that of the US (30.33). As Panel C shows, between 1989 and 2019, the P/E ratio for Tokyo Stock Exchange $1^{\text {st }}$ Section decreases from 70.60 to 23.00, and the P/E ratio for Nikkei 225 Index decreases from 57.00 to 19.15. While Japan's 1989 measures (70.60 and 57.00) are much higher than that of the US (15.24), its 2019 measures (23.00 and 19.15) are close to that of the US (22.75). As Panel D shows, Japan's P/B ratio reduces from 3.94 in 1989 to 1.36 in 2019 . While its 1989 measure (3.94) is much higher than that of the US (2.19), its 2019 measure (1.36) is much lower than that of the US (3.54).

TABLE 8

\section{RELATIVE VALUATION IN 1989 AND 2019}

Panel A. Market capitalization as $\%$ of GDP ${ }^{1}$

\begin{tabular}{|l|c|c|}
\hline & $\begin{array}{c}\text { Japan: } \\
\text { Listed domestic firms }\end{array}$ & $\begin{array}{c}\text { US: } \\
\text { Listed domestic firms }\end{array}$ \\
\hline Market cap as \% of GDP, end of 1989 & $139 \%$ & $60 \%$ \\
\hline Market cap as \% of GDP, end of 2019 & $122 \%$ & $178 \%$ \\
\hline
\end{tabular}

Panel B. Cyclically Adjusted PE (CAPE)

\begin{tabular}{|l|c|c|}
\hline & Japan: & US: \\
& Listed domestic firms & S\&P 500 Index \\
\hline CAPE, end of 1989 & 90.00 & 17.65 \\
\hline CAPE, end of 2019 & 22.09 & 30.33 \\
\hline
\end{tabular}

Panel C. P/E

\begin{tabular}{|l|c|c|c|}
\hline & $\begin{array}{c}\text { Japan: } \\
\text { Tokyo Stock Exchange } \\
1^{\text {st }} \text { Section }^{4}\end{array}$ & $\begin{array}{c}\text { Japan: } \\
\text { Nikkei 225 Index }\end{array}$ & S\&P 500 Index \\
\hline P/E, end of 1989 & 70.60 & 57.00 & 15.24 \\
\hline P/E, end of 2019 & 23.00 & 19.15 & 22.75 \\
\hline
\end{tabular}


Panel D. P/B

\begin{tabular}{|l|c|c|}
\hline & Japan & US \\
\hline $\mathrm{P} / \mathrm{B}$, end of $1989^{6}$ & 3.94 & 2.19 \\
\hline $\mathrm{P} / \mathrm{B}$, end of $2019^{7}$ & 1.36 & 3.54 \\
\hline
\end{tabular}

Sources: World Bank (data.worldbank.org) and other sources.

${ }^{1}$ Based on data from World Bank (data.worldbank.org).

${ }^{2}$ Based on data from Siblis's website (siblisresearch.com/data/japan-shiller-pe-cape).

${ }^{3}$ Based on data from Shiller's website (www.econ.yale.edu/ shiller/data.htm).

${ }^{4}$ Based on data from CEIC's website (www.ceicdata.com/en/indicator/japan/pe-ratio).

${ }^{5}$ Based on data from Nikkei's website (indexes.nikkei.co.jp/en/nkave/archives/data) and Hardy (1993).

${ }^{6} \mathrm{P} / \mathrm{B}$ is calculated as the multiplication of P/E and ROE. P/E and ROE are based on the data from Ide (1996).

${ }^{7}$ Based on the data from Factset. The Japanese data are the annual aggregate data of EWJ (ishares MSCI-Japan ETF). The US data are the annual aggregate data of SPY (SPDR S\&P 500 ETF).

\section{CONCLUSIONS}

Japan has a poor stock performance relative to the US over the entire three decades (1989-2019). To understand this matter, we investigate relevant issues across five areas and identify some serious and/or persistent problems that may explain it. Specifically, the problems about economic conditions involve some negative economic aspects such as slow GDP growth, high government debt, aging workforce, mild innovation, etc. The major problems about corporate governance contain weak legal protections and low governance ratings, and insiders-dominated and cross-holding ownership structure. The major problems about corporate financial policies denote excess financial assets. The major problems about corporate financial performance comprise low profitability and slow growth of EPS and revenues. Finally, the problems about relative valuation refer to the contraction of relative valuation measures.

All told, it is necessary to point out that Japan's slow GDP growth and slow EPS and revenue growth are not enough to explain its low stock return. That is to say, long-term stock performance, which reflects business value creation or destruction, is affected by not only hard issues (such as growth, productivity, and profitability) but also soft issues (such as legal protection, ownership structure, corporate policy makings, and market perception of business fundamentals).

Over the most recent decade (2009-2019), Japan has made progress in many facets, such as expansionary monetary policy, productivity growth, better corporate governance, increased dividend payments and stock repurchases, earnings growth, enhanced profitability, etc., resulting in an improved stock performance. Therefore, Japan's transformation is substantial, though it is gradual and incomplete.

\section{ENDNOTES}

1. GMI Ratings (formerly, Governance Metrics International) - Country Rankings as of September 27, 2010 (https://web.archive.org/web/20110125201141/http://www.gmiratings.com/Images/GMI_Country_Ranking s_as_of_10_27_2010.pdf)

2. Net buyback is the buyback minus the issuance of stock shares. If the net buyback is negative, then it means that issuance is larger than buyback. 


\section{REFERENCES}

Allen, F., Carletti, E., \& Grinstein, Y. (2018). International evidence on firm level decisions in response to the crisis: Shareholders vs. other stakeholders. Journal of The Japanese and International Economies, 47, 3-16.

Antoniou, A., Guney, Y., \& Paudyal, K. (2008). The determinants of capital structure: Capital marketoriented versus bank-oriented institutions. Journal of Financial and Quantitative Analysis, 43, 59-92.

Aono, K., \& Iwaisako, T. (2013). The consumption - Wealth ratio, real estate wealth, and the Japanese stock market. Japan and the World Economy, pp. 25-26, 39-51.

Aoyagi, C., \& Ganelli, G. (2017). Unstash the cash! Corporate governance reform in Japan. Journal of Banking and Financial Economics, 1, 51-69.

Azar, J.A., Kagy, J-F., \& Schmalz, M.C. (2016). Can changes in the cost of carry explain the dynamics of corporate cash holdings? Review of Financial Studies, 29, 2194-2240.

Bird, M. (2019a, May 22). Bank of Japan shows how not to buy stocks - Market seems unimpressed by ETF purchases. Wall Street Journal, p.B16.

Bird, M. (2019b, November 27). 'Japanification' not bad for investors. Wall Street Journal, p.B14.

Bird, M. (2019c, December 12). Japan keeps repeating its mistakes - A sales-tax increase once again dents the nation's economy more than Tokyo anticipated. Wall Street Journal, p.B12.

Bird, M. (2020, February 19). Japan's third sales-tax blunder had better be its last. Wall Street Journal, p.B14.

Chan, L.K.C., Hamao, Y., \& Lakonishok, J. (1991). Fundamentals and stock returns in Japan. Journal of Finance, 46, 1739-1764.

Chan, L.K.C., Hamao, Y., \& Lakonishok, J. (1993). Can Fundamentals Predict Japanese Stock Returns? Financial Analysts Journal, 49, 63-69.

Chen, S. (2012). The predictability of aggregate Japanese stock returns: Implications of dividend yield. International Review of Economics and Finance, 22, 284-304.

Chernenko, S., Foley, C.F., \& Greenwood, R. (2012). Agency costs, mispricing, and ownership structure. Financial Management, 41, 885-914.

Cowling, K., \& Tomlinson, P.R. (2000). The Japanese crisis - A case of strategic failure? The Economic Journal, 110, F358-F381.

Curran, R. (2018). Is Japan ready to grow again? Money, 47, 24-24.

Damodaran, A. (2014). Applied Corporate Finance. John Wiley \& Sons, Inc.

Dewenter, K.L., \& Warther, V.A. (1998). Dividends, asymmetric information, and agency conflicts: Evidence from a comparison of the dividend policies of Japanese and U.S. Firms. Journal of Finance, 53, 879-904.

Diamond, J. (2011). Essays on the Japanese labor market. UC San Diego: Economics. b7075307. Retrieved from http://escholarship.org/uc/item/67v3b94h

Dittmar, A., Mahrt-Smith, J., \& Servaes, H. (2003). International corporate governance and corporate cash holdings. Journal of Financial and Quantitative Analysis, 38, 111-133.

Doidge, C., Karolyi, G.A., \& Stultz, R.M. (2007). Why do countries matter so much for corporate governance. Journal of Financial Economics, 86, 1-39.

Fama, E.F., \& French, K.R. (2012). Size, value, and momentum in international stock returns. Journal of Financial Economics, 105, 457-472.

Franks, J., Mayer, C., \& Miyajima, H. (2014). The Ownership of Japanese Corporations in the 20th Century. The Review of Financial Studies, 27, 2580-2625.

Fujikawa, M., \& Narioka, K. (2019 April 1). Some want Japan to embrace debt. Wall Street Journal, p.A2.

Fukuda, S-I. (2018). Impacts of Japan's negative interest rate policy on Asian financial markets. Pacific Economic Review, 23, 67-79. 
Fukuda, S-I., \& Yamada, J. (2011). Stock price targeting and fiscal deficit in Japan: Why did the fiscal deficit increase during Japan's lost decades? Journal of The Japanese and International Economies, 25, 447-464.

Fukuta, Y., \& Yamane, A. (2015). Value premium and implied equity duration in the Japanese stock market. Journal of International Financial Markets, Institutions \& Money, 39, 102-121.

Glassman, J.K. (2018). A cautious plan to invest in Japan. Kiplinger's Personal Finance, 72, 16-18.

Hamao, Y., \& Matos, P. (2018). U.S.-style investor activism in Japan: The first ten years? Journal of the Japanese and International Economies, 48, 29-54.

Hardy, Q. (1993, February 4). Pension money flows to Japan. Wall Street Journal, p.C1.

Hausman, J.K., \& Wieland, J.F. (2015, Fall). Overcoming the lost decades? Abenomics after three years, Brookings Papers on Economic Activity, pp. 385-413.

Hirakata, N., Sudo, N., Takei, I., \& Ueda, K. (2016). Japan's financial crises and lost decades. Japan and the World Economy, 40, 31-46.

Hoshi, T., Koibuchi, S., \& Schaede, U. (2018). The decline in bank-led corporate restructuring in Japan: 1981-2010. Journal of The Japanese and International Economies, 47, 81-90.

Ide, M. (1996). Corporate profitability and stock valuation in Japan. Financial Analysts Journal, 52, 40-55.

Ikeda, N., Inoue, K., \& Watanabe, S. (2018) Enjoying the quiet life: Corporate decision-making by entrenched managers. Journal of The Japanese and International Economies, 47, 55-69.

Kang, J-K., Shivdasani, A., \& Yamada, T. (2000). The effect of bank relations on investment decisions: An investigation of Japanese takeover bids. Journal of Finance, 55, 2197-2218.

Kato, K., Li, M., \& Skinner, D.J. (2017). Is Japan really a "buy"? The corporate governance, cash holdings and economic performance of Japanese companies. Journal of Business Finance \& Accounting, 44, 480-523.

Khoo, J., \& Durand, R.B. (2017). Japanese corporate leverage during the lost decades. Pacific-Basin Finance Journal, 46, 94-108.

Khurana, I.K., Martin, X., \& Pereira, R. (2006). Financial development and the cash flow sensitivity of cash. Journal of Financial and Quantitative Analysis, 41, 787-807.

Koller, T., Goedhart, M., \& Wessels, D. (2015). Valuation: Measuring and Managing the Value of Companies. John Wiley \& Sons, Inc.

Kubota, K., \& Takehara, H. (2018). Does the Fama and French five factor model work well in Japan? International Review of Finance, 18, 137-146.

L'Her, J-F., Masmoudi, T., \& Krishnamoorthy, R.K. (2018). Net buybacks and the seven dwarfs. Financial Analysts Journal, 74, 57-85.

La Porta, R., Lopez-de-Silanes, F., Shleifer, A., \& Vishny, R.W. (1998). Law and finance. Journal of Political Economy, 106, 1113-1155.

La Porta, R., Lopez-de-Silanes, F., Shleifer, A., \& Vishny, R.W. (2000a). Investor protection and corporate governance. Journal of Financial Economics, 58, 3-27.

La Porta, R., Lopez-de-Silanes, F., Shleifer, A., \& Vishny, R.W. (2000b). Agency problems and dividend policies around the world. Journal of Finance, 55, 1-33.

La Porta, R., Lopez-de-Silanes, F., Shleifer, A., \& Vishny, R.W. (2002). Investor protection and corporate valuation. Journal of Finance, 57, 1147-1170.

Luo, Q., \& Hachiya, T. (2005). Corporate governance, cash holdings and firm value: Evidence from Japan. Review of Pacific Basin Financial Markets and Policies, 8, 613-636.

Mackintosh, J. (2019, March 20). Japan is back as a role model. Wall Street Journal, p.B1.

Mehrotra, V., van Schaik, D., Spronk, J., \& Steenbeek, O. (2011). Creditor-focused corporate governance: Evidence from mergers and acquisitions in Japan. Journal of Financial and Quantitative Analysis, 46, 1051-1072.

Miyajima, H., Ogawa, R., \& Saito, T. (2018). Changes in corporate governance and top executive turnover: The evidence from Japan. Journal of the Japanese and International Economies, 47, 17-31.

Miyazawa, K. (2012). Capital utilization in Japan's lost decade: A neoclassical interpretation. Japan and the World Economy, 24, 246-253. 
Morck, R., Nakamura, M., \& Shivdasani, A. (2000). Banks, ownership structure. and firm value in Japan. The Journal of Business, 73, 539-567.

Mun, K-C. (2012). The joint response of stock and foreign exchange markets to macroeconomic surprises: Using US and Japanese data. Journal of Banking and Finance, 36, 383-394.

Pinkowitz, L., \& Williamson, R. (2001). Bank power and cash holdings: Evidence from Japan. The Review of Financial Studies, 14, 1059-1082.

Pinkowitz, L., Williamson, R., \& Stulz, R.M. (2007). Cash holdings, dividend policy, and corporate governance: A cross-country analysis. Journal of Applied Corporate Finance, 19, 81-87.

Prowse, S. (1992). The structure of corporate ownership in Japan. Journal of Finance, 47, 1121-1140.

Ramdhan, N'A., Yousop, N.L.M., Ahmad, Z., \& Abdullah, N.M.H. (2018). Long run economic forces in the Japan and United State stock market. Global Business and Management Research, 10, 277289.

Rattner, S. (2013, October 20). The lessons of Japan's economy. The New York Times, p.14.

Richards, B. (2017). 14 fascinating facts about Japanese stocks - from 1989. Retrieved from http://www.fool.com/investing/2017/05/23/14-fascinating-facts-about-japanese-stocks-from19.aspx

Riddick, L.A., \& Whited, T.M. (2009). The corporate propensity to save. Journal of Finance, 64, 17291766.

Schaede, U. (2012). From developmental state to the 'New Japan': The strategic inflection point in Japanese business. Asia Pacific Business Review, 18, 167-185.

Tong, J., \& Bremer, M. (2016). Stock repurchases in Japan: A solution to excessive corporate saving? Journal of The Japanese and International Economies, 41, 41-56.

Warnock, E. (2016, February 18). Global finance: Japan pension stock plan shelved - critics say move would have caused excessive state influence on market. Wall Street Journal, p.C3.

Yanagi, R. (2018). Corporate governance and value creation in Japan: Prescriptions for boosting ROE. Springer.

Yoshimori, M. (1995). Whose company is it? The concept of the corporation in Japan and the west. Long Range Planning, 28, 33-44. 